\title{
Brazil, China, US: a triangular relation?
}

Brasil, China, EUA: uma relação triangular?

http://dx.doi.org/10.1590/0034-7329201400207

JOSÉ-AUGUSTO GUILHON-ALBUQUERQUE*

Rev. Bras. Polit. Int. 57 (special edition): 108-120 [2014]

\section{Brazil-China strategic partnership}

The expression "strategic partnership" was applied to Brazil's bilateral relation with China during the Itamar Franco government (1992-1994), and remained in use throughout the Fernando Henrique Cardoso government (1995-2002). Generally speaking, the expression assigns a special nature to the relationship between the two countries.

It was not until the Lula government (2003-2010), however, that bilateral relations between Brazil and China actually became unique, thanks to a combination of extraordinary growth in the flow of trade and investment between the two countries, with priority being given to South-South relations during Lula's term. During his government, and specifically as a result of the 2008 crisis, China became Brazil's biggest single partner in trade and investment, second only to the $\mathrm{EU}$ and, in stock of investments, to the USA.

During his time in government, Lula made two official visits to China-in 2004 and 2009-, and twice received visits from President Hu Jintao. According to his own count, Lula met his Chinese counterpart a total of nine times between 2008 and 2009, an impressive number. So, the uniqueness of the relationship between the two countries cannot be ignored, but this does not in itself define the nature of the relationship. Neither the extent nor the strategic nature of the partnership is clear. The expression "strategic partnership" seems, above all, to be a metaphor for the priority given by both governments to the growing volume of trade and investment between the two countries and to Brazil's aspiration to build closer political ties with the Asian giant.

A number of authors emphasize the strategic role of Brazil's partnership with China as part of the Lula government's priority for South-South cooperation

* University of São Paulo, São Paulo, SP, Brazil (guilhon@usp.br). 
(Cunha 2004, Oliveira 2004, 2006) as an alternative to what had been the predominant trend up to that time, of insertion of Brazil into the economy of developed countries.

Nevertheless, one of the most respected experts on Brazil's priority to South-South cooperation, Prof. Maria R.S. Lima, in a 2005 article $^{1}$, does not give a single mention to China as a protagonist of this strategic South-South cooperation process.

Besides, the concept of strategic partnership is almost totally absent in two dossiers organized by the prestigious Brazilian Center for International Relations (CEBRI) a think tank created by the Brazilian diplomatic establishment, the first in 2008, on Challenges of Brazilian Foreign Policy, and the other on Priorities for Brazilian Foreign Policy in the Light of National Interest ${ }^{2}$.

In the 51 essays contributed by diplomats, business people, politicians, and academics, we find no references to China either as a challenge to, or target of national interest. Among these essays, Celso Amorim, then Foreign Minister, mentions China just once, when listing the BRICs countries. The former Brazilian president Fernando Henrique Cardoso also mentions China only en passant ${ }^{3}$ and Ms. Lima, in an essay summarizing her own arguments in the aforementioned article, mentions China just once, in a list including India, Mexico, and South Africa.

Given this lack of correspondence between the relevance attributed to the strategic nature of Brazil-China partnership, its central role in defining Lula's innovative foreign policy, and its ambiguous presence in the literature, it seems necessary to examine how this partnership is manifested in the presidential discourse.

To achieve this aim, I have undertaken a study about perceptions of China and the nature and substance of its strategic partnership with Brazil, through an analysis of President Lula's speeches and interviews during his second visit to China in $2009^{4}$.

In that occasion, the Brazilian President had the benefit of six years of intense relations with China, and the issue of substance and scope of the strategic partnership between the two countries was one the central theme of all his speeches, interviews, and deals signed by him.

\footnotetext{
1 Lima, M. R. S. "A Política Externa Brasileira e os Desafios da Cooperação Sul-Sul" (Brazilian foreign policy and the challenges of South-South cooperation), Revista Brasileira de Política Internacional, Ano 48, no. 1, 2005, p. 24-59.

2 CEBRI, Desafios da Politica Externa Brasileira (Challenges of Brazilian foreign policy), DOSSIÊ, Edição Especial, vol. 1, Ano 7, 2008, 95p; and CEBRI, Prioridades da Politica Externa Brasileira à Luz do Interesse Nacional (Priorities for Brazilian foreign policy in the light of national interest), vol. 1, Ano 9, 2010, 100p.

3 CEBRI 2008, p. 17, 23 and 64 respectively.

4 In the present section I partly summarize the findings of that survey, published on: ALBUQUERQUE, J. A. G., "Business with China: the three elements of Brazil's strategic partnership with China", in Leila Ferreira and J. A. Guilhon Albuquerque: China \& Brazil: challenges and opportunities, São Paulo, Annablume, 2013, p. $67-90$.
} 
In two speeches and three interviews 5 all actors, actions, and relationships found in the official texts referred here, we observed the presence of three dimensions in all direct and indirect references to the notion of "strategic partnership."

The most common dimension in all the presidential discourse, and occurring most often by far, is the dimension of trade and investment. In all his references to China and its relationship with Brazil, Lula refers to trade and investment flow between the two countries, both to exemplify the nature of the relationship, and also to justify its unique character. The principal corollary of the existence of a unique relationship — whether labeled as strategic or not-is, therefore, the existence of a highly relevant trade flow, with an exponential growth rate and with an expected potential frequently emphasized as being "infinite." And this to the extent that the corollary becomes, in practice, a synonym of the strategic partnership.

In fact, at his first press conference in Beijing (press conference 20.05.09), when asked "what is the current state of the strategic association between the two countries?”, Lula began his reply by focusing exclusively on trade:

Well, firstly, it is extremely auspicious for Brazil and for China that as we mark 35 years of diplomatic relations, China has become Brazil's main trade partner. In the first four months of this year, China overtook the United States. (press conference May 20, 2009).

The second most common dimension in the presidential discourse is that of international partnership, which involves a division of tasks and common objectives for both countries. Some of the references imply cooperation with division of tasks and refer directly to objectives for facilitating, widening, and diversifying trade flow.

Generally speaking, though, Lula refers to the division of tasks necessary to achieve common objectives not limited to bilateral trade, whether political or economic. Still responding on the issue of the strategic partnership, the following quotation clearly outlines the non-trade dimension of the partnership:

We are two large countries with extraordinary possibilities for working together. In the areas of oil, agriculture, space research, scientific exchange... [...] Why? Because China and Brazil play an extremely important role in multilateral forums, in the G20. (press conference May 20, 2009)

The passage below, from the same interview, clearly shows a distinction between the two dimensions of the Brazil-China partnership as perceived by the

5 An exclusive interview given in writing to the Xinhua news agency just before the visit (Exclusive interview 16.05.09); The speech made at the inauguration of the Brazilian Studies Center of the Chinese Academy of Social Science (Speech at the Center for Brazilian Studies May 19, 2009); The closing speech at the Brazil-China Seminar New Opportunities for the Strategic Partnership (Speech at the New Opportunities seminar May 19, 2009); A press conference for Chinese media (press conference May 20, 2009); A press conference following the signing of agreements at the Chinese Academy of Space Technology (Space Technology press conference May 20, 2009). 
Lula government. Here, Lula describes a characteristic defined as intrinsic to the strategic partnership between the two countries and, in doing so, gives bilateral trade issues as an example. Subsequently, his reply returns to the strategic partnership, justifying the partnership with an example of how collaboration between the two countries carries the aim of acting beyond the bilateral scope:

Our strategic partnership calls for greater boldness in the relationship between the two countries. [...] It often seems as though we are not united because we compete on the same market with some of our products. [...] But, apart from this, China and Brazil have behaved exceptionally well in relation to multilateral parameters (press conference 20.05.09).

Curiously, this reply has the same structure as the previous one, in which, after stating the extraordinary potential of working together, Lula first gives the examples of commodities trade and cooperation in science and technology, to then justify this with: "Why? Because China and Brazil play an extremely important role in multilateral forums, in the G20." Thus, trade is the most easily retrievable example of the potential of bilateral relations, whereas the aspect used to justify the partnership is the objective to be attained in international forums.

The third dimension is that of identity. This dimension differs from that of trade and international partnership in that it is not necessarily a result of action by the two countries, but of geographical or historical affinities.

The affinities evoked in Lula's discourse-geographical size, similarities between the economies, stage of development, and common needs-do not constitute a planned relationship between the two countries, rather, they are mentioned in order to justify and determine both the flow of trade and investment, and the existence of international partnership.

This identity is based in the similarity of level of the development. For Lula, it is this similarity, rather than the complementarity, that would be the principal factor for potential growth in trade and investment. This is clear in the following passage:

I have no doubt that the relationship between China and Brazil will only increase. I would go so far as to say that the relationship is almost infinite, such are the needs of Brazil, such are the needs of China, such is the potential of China and the potential of Brazil. (Space Technology press conference May 20, 2012).

Or:

You just have to look at the trade balance between Brazil and rich countries, analyze the trade balance between Brazil and Argentina, between Brazil and China, between Brazil and Venezuela, between Brazil and Colombia, then you will see that precisely because we are very similar and are more or less equal, 
we sell more to each other than to the rich countries, who only want to sell because they are the keepers of technology. (Space Technology press conference May 20, 2012).

Within his descriptions of bilateral relations with China, Lula employs other dimensions that we could consider as residual, such as cultural and political relations, and cooperation in technology. These references are essentially enumerative. That is, they are evoked in order to give a wider context to the strategic partnership. Consequently, these relationships are listed side by side in the discourse with the aspects granted greater relevance, that is, the identity determining the potential of bilateral trade and investment flows, with these residual dimensions added on as justification for the international partnership. However, after having been listed to fulfill, so to speak, their contextualizing role, they then disappear from the discourse.

As opposed to being independent, the three dimensions in Lula's speech on Brazil-China strategic partnership fit into a hierarchical structure in a nexus of causal determination. The three dimensions of the partnership pointed out in Lula's discourse are the identity between the two countries, the growing volume of bilateral trade and investments, and cooperation in international forums. The factor determining the partnership is identity, which includes variables such as level of economic development, existence of a large and rapidly expanding internal market, and lack of basic, physical, and service infrastructure.

The second dimension of the partnership, the bilateral trade and investments dimension is a consequence of the basic identity between the two countries. This identity, in particular in relation to the needs of each of the two countries-i.e. demand for mass products and new technology — is the principal factor determining the rapid growth in trade and investment between the two countries It justifies the large potential for that trade and investment, which are the relevant variables of the bilateral trade element. Bilateral trade, in turn, has strengthened the identity between the two economies since they were drawn together at the center of the world stage during the 2008 crisis $^{6}$. This process of being drawn together to the world forums of international decision making, adds new variables to the basic identity between levels of economic and social development. Consequently, the identity between Brazil and China becomes enriched with new aspects, such as a common lack of voice and decision-making powers in international financial and political forums, which this partnership will address.

Therefore, the international partnership dimension, like the bilateral trade element, is also determined by the identity between the two countries. Consequently, the set of affinities that already determines the existence and great potential for

6 Lula's interpretation is a little different. The access of the BRIC countries into the G-20 and the new voice they acquired at institutions such as the IMF and the World Bank are factors attributed by Lula to fiscal politics and to public investment programs adopted by the BRIC governments, and not principally to the fact of these countries being less affected by the credit crisis and being responsible for the little that remained of international trade and of the countries attractiveness to foreign investments. 
bilateral trade relations brings a further dimension to the partnership between the two countries, to the extent that it highlights possibilities of acting beyond bilateral relations, and of sharing tasks in order to achieve common goals.

Whenever this new dimension of international partnership appears in the discourse, it is associated with the identity between the two countries and the international significance acquired by the two economies, as a result of that identity.

A possible conclusion of this brief analysis is that, from Lula's government viewpoint, China-Brazil bilateral relations consist in a three-dimensional partnership based on their common identity as developing countries. Therefore it is very much distinct from other bilateral North-South relations.

Another aspect concerns its international cooperative dimension as highlighted by the role both countries undertake in global forums.

Some preliminary results of a new and larger study about the Brazilian government's perceptions of its strategic partnership with China add a fresh perspective 7 . This study encompasses both Lula's and Dilma Rousseff s governments ${ }^{8}$ and sheds a slightly new light on the subject. The comments bellow refer to her first visit to China and are centered on her official opening speech at the main public seminar.

At first sight Rousseff's perception of a strategic partnership with China is rather indistinguishable from Lula's. The three dimensions noticed in his discourse are equally present in hers: identity (common socio-economic conditions), relevance of trade and investments flow, and cooperation in international forums. Despite the same references and almost the same words, President Rousseff tries and establishes a discontinuity between her mandate and the previous one.

While stressing the same evidences of the growing interdependence between the two economies, she claims to be starting a new era of partnership and gives a new sense to the international cooperation between the two countries. After having emphasized the relevance of bilateral trade, Rousseff asserts the need to go beyond complementarity between the two economies:

We need to go beyond the complementarity of our economies, despite its importance. And we need to go beyond complementarity to facilitate a more dynamic, diversified and balanced relationship?.

Along the speech other additional references to her wish to take a step forward are underlined, like for instance: "We want to make a qualitative leap...", or "Besides trade partnership we also want to become partners in investment opportunities in joint businesses, in services and in innovation."

7 This study has been undertaken with a grant from São Paulo State Science Foundation (FAPESP).

8 President Rousseff was inaugurated in January 1s, 2011 and her term runs through December 312014.

9 Seminar: "Brasil-China: Para Além da Complementaridade" (Brazil-China: Beyond Complementarity) (Pequim, 12.04.2011). 
One phrase summarizes the sentiment of going beyond trade:

My visit to China inaugurates a new chapter in our relationship.

In fairness we might admit that Lula made similar claims about the need to upgrade Brazilian exports to China and to cooperate with China in technological innovation. Moreover, similar examples of this new level of trade are given by both: space and aviation industry, bioenergy, and so on.

It would be safe to say that Lula and Rousseff name the same things differently and that she looks for change where he only sees continuity.

A second difference refers to the principle on which the partnership is based. As we have seen above, Lula assigns the special relationship between Brazil and China to their common identity as developing countries. His enumeration of socio-economic similarities comes as a mantra in his speeches about their strategic partnership.

In Rousseff s discourse, though, the relevant factors are the actors, their attitudes and feelings. In her opening statements at the already mentioned seminar, she could not be clearer:

I know that building mutual confidence between Brazil and China depends on the intensification of the dialogue;

Our (visiting) party reflects the political will of my country's government and society;

We have been building a solid relationship based on friendship and on the continuous rapprochement between our people and our leaders.

Finally, another almost negligible difference concerns the international dimension of the strategic partnership. As we have discussed above, from Lula's point of view, international cooperation with China in global forums is associated with the identity between the two countries and the international significance acquired by the two economies, as a result of that identity. Lula clearly avoids any revisionist stance and instead claims for an upgraded participation in the G-20, the IMF and the World Bank.

Here too, Rousseff apparently wants to "go beyond." While mentioning the same examples of a shared international decision making role as Lula, she further mentions ideas that are absent of Lula's speeches. One has the impression that she is adhering to a search for a new world order.

In a context in which she lists the many instances of Brazilian access to international regimes and organizations, Rousseff refers to her country's contributions to tackling global challenges: 
At a time when the Planet faces unprecedented challenges, we are joining forces and projecting alternative visions, [...] we are helping... to build a new international order.

Despite this emphasis on an alternative world order, both Rousseffs and Lula's discourses are conspicuously silent about international politics and regional cooperation in matters other than trade, investments and global finance. China is becoming a relevant regional stakeholder in the Americas, including in Brazil's closest area of influence, South America. The chances for cooperation and conflict between Brazilian and Chinese interests in such a context are increasing as are increasing the chances for rivalry and conflict between China and the US our two most important partners in trade and investment.

Similarly, China's growing clout over the African continent regards Brazilian second most important strategic region, one that shares with Brazil common security challenges in the Southern Atlantic. As we shall discuss bellow, the chances for cooperation and conflict involving Brazil, the US and China are also increasing.

Oddly enough the very concept of strategic partnership in the Brazilian government perception seems to ignore the political dimension of the two countries' bilateral relations. That's the reason why we include these questions in our final recommendations.

\section{Brazil-China partnership and the US}

Now we shall turn to the impact of Brazil-China partnership on BrazilUS relations. Presently, the core interests and goals of the US are arguably overdetermined by two independent but interconnected challenges: the first one is the US role in global governance; and the other is China's rise.

Comparing to the Cold War period, the role of prime guarantor of global governance involves bigger and growing costs, because its challenges are more complex, especially for a country whose resources of power and influence are declining. The declining ability of the US to exert indisputable global primacy is a consequence of its domestic economic imbalance which, in turn, is closely associated to the deterioration of the process of settling domestic political conflicts.

Besides, the US is involved in a severe crisis of external credibility deriving both from its role in triggering the global financial crisis and its recent record of disastrous military interventions, which in turn negatively affect the country's stock of soft power. Obama's recent about-face on a red-line not to be crossed by Assad's government in Syria's civil war does not add to his country's credibility concerning its ability to lead global affairs ${ }^{10}$.

10 Vali Nasr, The dispensable Nation. American Foreign Policy in Retreat, N.Y., Doubledeay, 2013; Richard Haass, Foreign Policy Begins at Home. A Case for Putting America's House in Order, N. Y., Basic Books, 2013. 
China's rise poses an additional systemic challenge to US' global leadership. Chinese global performance has proved bolder than expected in several dimensions- be it on the economic and financial field, in expanding its military clout, or even in terms of territorial claims. More importantly China's assertiveness has been directed to all continents, causing US' trade and investment relevance and to some extent its political and military leadership to be challenged ${ }^{11}$. As a consequence, it becomes ever more difficult for the US to face strategic challenges anywhere in the world, including in Latin America, without taking into account the PRC's core interests and political priorities ${ }^{12}$.

Among US strategic priorities in this new framework of international power, the search for a domestic rebalancing of the economy and the internal political decision making is paramount. This rebalancing is particularly vital as regards the American political system inter-institutional relations, pointed out by many authors as a condition sine qua non for the country to keep on performing its global leadership. To achieve this rebalancing it's imperative to recover US' relevance-its primacy if possible-in global trade and investment, which has been worn down by China's global progress.

Obama's initiatives to revitalize the APEC, together with relaunching the trade and investment talks with the EU and the big boost given to the Trans Pacific Partnership seem to converge in this direction. Concerning the TPP talks we should note that the Obama administration is trying to attract key countries in Latin America-Mexico, Peru, Colombia, Chile and also Paraguay and Uruguay-as part and parcel of its global strategy. It's an unprecedented initiative in a region always considered as an extension of the US domestic priorities ${ }^{13}$.

Let's turn to the impact of China's rise on Brazil-US bilateral relations. The growing presence of Chinese trade and investment is becoming ever more visible in Latin America and even in the Caribbean, in such way that we might admit that a triangular relation among the three countries is a possibility not to be dismissed.

The case of Brazil is emblematic once since 2009 China has become our principal trade partner. Besides, Brazil alignment with China in the UN Security Council, as well as in other UN forums and agencies is currently more relevant than with the US or other permanent members of the Security Council. Moreover, the opportunities for a South-South sort of cooperation between the Brazil and China are manifold, especially when we take into account the so-called strategic partnership. The potential for such cooperation to affect, or to be affected by US

11 See David Shambaugh, China Goes Global. The Partial Power, N. Y. Oxford University Press, 2013, especially chap. 3: "China's Global Diplomatic Presence"

12 Sanchita Basu Das, "Trans-Pacific Partnership as a tool to Contain China: Myth or Reality?", ISEAS perspective, \#31 17 May 2013; Daljit Singh, "Pivoting Asia. Engaging China-American Strategy in East Asia Today", ISEAS perspective, 19 Oct 2012.

13 R. Evan Ellis, The United States, Latin America and China: A “Triangular Relationship?”, Inter-American Dialogue Working Paper, May 2012. 
interests in Brazil is significant. The same applies to Chinese interests being affected by a possible increase in Brazil-US cooperation in Africa or in Asia, especially in East-Asia.

In the case of Africa, Brazil and the US have a record of friction in different periods. Brazil has consistently opposed US decolonization policies concerning the Portuguese colonies but, in the late process of independency, after democratization in Portugal, in a period of strong attrition between the Brazilian military government and the US, Brazilian diplomatic activism in Angola was crucial for the international recognition of the new regime, forcing the US to follow. Furthermore, the new South-South activism of Lula's government towards Africa, as a part of a sort of pivot of Brazilian foreign policy to the "South" is that it breaks new ground for mutual interferences between the two countries' policies in the region.

\section{Brazil's contributions to global governance: recommendations}

Finally we can evaluate possible areas of synergy in Brazilian bilateral relations with the two countries and make some recommendations. First let's enounce a general recommendation, which consists in adopting a rule of systemic caution: let's reserve any final prognostic about the outcome of the current transition in the system of international power. The post-Cold War transition went through different phases but it is still far away from its end point.

China is undoubtedly a rising power but even if it outgrows the American economy, US primacy might prevail for a long time. Granted Chinese peculiarities and serious imbalances, it is impossible to predict when the conditions for competing with the US for global leadership would eventually be given. For similar reasons it is impossible to predict if such leadership transition will result in a soft landing, making possible a peaceful realignment such as the one that occurred between the British Empire and the US in early $20^{\text {th }}$ century.

The second recommendation concerning Brazil's contribution to global governance is for the country to concur to a peaceful transition of the international system of power. It is in Brazil's core interests to avoid a tumultuous world order. Brazil can only concur to such a goal avoiding an exclusive alignment with China or the US. It would require to try and reduce rivalries, to avoid taking sides in conflicting situations, and to advance in every possible stance, a positive agenda.

In a number of global stages Brazilian contribution is becoming more relevant. In the quest for a sound global financial governance, Brazilian opportunities to participate are increasing. In this respect Brazil should contribute to mitigate conflicts and not to spur attritions.

A more specific role derives from Brazilian unique ability to contribute for regional governance, both in Latin America and in Africa. In the case of the Western Hemisphere agenda, there is a potential for conflicts consisting in a tendency for dichotomic perception of the region, which opposes the strategic interests of the 
US to the rest of the region. Brazil has a clear national interest in preserving the political and economic convergence in the Continent. In that sense the country should adopt two courses of action.

First, Brazil should try and reverse the centrifugal trends, notably in Mercosur and Unasur, avoiding unnecessary conflicts, especially those opposing the Bolivarian countries to Chile, Peru, Colombia, Mexico, and even Paraguay and Uruguay. A subsequent step would consist in adopting a common positive agenda, for instance in clean energy and infrastructure. Even if a common agenda is difficult to achieve, a reduction in the conflictive tendency in the region meets the best interest of Brazil, the US and China.

Another instance concerns cooperation and conflict among the three countries in Africa, where Brazil sustains an activist foreign policy, China moves forward in every domain — trade and investments, infrastructure, mining, etc. - and the US, while losing ground, has a record of humanitarian and development aid, occasionally in close collaboration with Brazil (combating AIDS and malaria, for instance).

Despite the difficulties inherent to this sort of cooperation, Brazil has accumulated a record of triangular cooperation with third parties in Africa, in collaboration with such countries as Sweden and the US. Besides, Brazil has pioneered the development of technology for sustainable energy and tropical agriculture. Nevertheless it is difficult to predict China's reaction to an increase of Brazilian involvement on Africa, let alone in collaboration with the US. Anyway, Brazilian diplomats have received from Chinese sources positive signs concerning common projects of cooperation and investments in Africa.

For the same purpose of providing a common positive agenda with the US and China, Brazil should reconsider its international trade agenda. Since President Lula took the decision to abort the FTAA talks, the Brazilian government bet all of the chips on the WTO Doha round, to the detriment of Mercosur and other relevant trade negotiations, as those concerning EU/Mercosur talks. Brazilian interest in keeping the Doha round alive is reasonable, but giving it such an exclusive importance is not in the country's best interest, given that all relevant WTO stakeholders are currently prioritizing bilateral, multilateral or regional negotiations.

Denying exclusivity to Doha opens the doors to a reappraisal of the most important negotiations currently available, involving our principal trade partnersUS, EU and China. In this sense it is recommendable at least to apply for an observer status at the Pacific Alliance, the Trans Pacific Partnership and the Regional Comprehensive Economic Partnership (RCEP). The Transatlantic Trade and Investment Partnership, whose impact on the governance of international trade might be huge, affecting profoundly Latin American economy, if it ever makes progress, it should be closely followed by the Brazilian diplomacy.

In a nutshell, Brazil's most important regional goal should consist in concurring to facilitate a convergence in the Western Hemisphere, avoiding 
centrifugal trends. From a global point of view, Brazil should concur to mitigate the rivalry between the US and China and contribute to a peaceful global transition resulting from China's rise.

\section{Bibliographic references}

ALBUQUERQUE, J. A. G., "Pressupostos Teóricos e Metodológicos da Análise de Discurso", in Chaia V., Resende P.-E. e Almeida, L. F. R., Análise do Discurso Politico, São Paulo, Educ, 1993, p. 71-79.

ALBUQUERQUE, J. A. G., "Business with China: the three elements of Brazil's strategic partnership with China", in Leila Ferreira and J. A. Guilhon Albuquerque: China \& Brazil: challenges and opportunities, São Paulo, Annablume, 2013, p. 67-90.

CEBRI, Desafios da Política Externa Brasileira, DOSSIÊ, Edição Especial, vol. 1, Ano 7, 2008, $95 \mathrm{p}$.

CEBRI, Prioridades da Política Externa Brasileira à Luz do Interesse Nacional, DOSSIÊ, Edição Especial, vol. 1, Ano 9, 2010, 100 p.

CUNHA, L. F., Em Busca de um Modelo de Cooperação Sul-Sul: o Caso da Área Espacial nas Relações entre o Brasil e a República Popular da China, (1980-2003), Dissertação de mestrado, Universidade de Brasília, 2004.

DAS, SANCHITA BASU, "Trans-Pacific Partnership as a tool to Contain China: Myth or Reality?”, ISEAS perspective, \#31 17 May 2013.

ELLIS, R. EVAN, The United States, Latin America and China: A “Triangular Relationship"?, Inter-American Dialogue Working Paper, May 2012.

HAASS, RICHARD, Foreign Policy Begins at Home. A Case for Putting America's House in Order, N. Y., Basic Books, 2013.

LIMA, M. R. S., "A Política Externa Brasileira e os Desafios da Cooperação Sul-Sul", Revista Brasileira de Politica Internacional, Ano 48, no. 1, 2005, p.24-59.

NASR, VALI, The dispensable Nation. American Foreign Policy in Retreat, N.Y., Doubledeay, 2013.

OLIVEIRA, H. A., "O Brasil e a Ásia", in Lessa A. C. e Oliveira H. A., Relações Internacionais do Brasil, São Paulo, Saraiva, 2006, cap 6, Parte 2, p. 169-201.

OLIVEIRA, H. A., "Brasil-China: trinta anos de uma parceria estratégica", Revista Brasileira de Politica Internacional", Ano 47, no. 1, 2004, p. 7-30.

MRE, Entrevista exclusiva por escrito do Presidente Luís Inácio Lula da Silva à Agência Xinhua, 16/05/09. (Exclusive interview given in writing by President Luís Inácio Lula da Silva to the Xinhua Agency, 16/05/09).

MRE, Discurso do Presidente Luis Inácio Lula da Silva na inauguração do Centro de Estudos Brasileiros da Academia de Ciência Sociais da China, 19/05/09. (Speech made by President Luis Inácio Lula da Silva at the inauguration of the Center for Brazilian Studies of the Chinese Academy of Social Science, 19/05/09). 
MRE, Discurso do Presidente Luis Inácio Lula da Silva no encerramento do Seminário "Novas Oportunidades da Parceria Estratédgica", 19/05/09. (Speech made by President Luis Inácio Lula da Silva at the closing of the seminar "New opportunities for the strategic partnership", 19/05/09).

MRE, Entrevista coletiva do Presidente Luis Inácio Lula da Silva a jornais chineses, 20/05/09. (Press conference given by President Luis Inácio Lula da Silva to Chinese newpapers, 20/05/09).

MRE, Entrevista coletiva do Presidente Luis Inácio Lula da Silva após assinatura de atos oficiais na Academia Chinesa de Tecnologia Espacial, 20/05/09. (Press conference given by President Luis Inácio Lula da Silva after signing official agreements at the Chinese Academy of Space Technology, 20/05/09).

SHAMBAUGH, DAVID, China Goes Global. The Partial Power, N. Y. Oxford University Press, 2013, especially chap. 3: "China’s Global Diplomatic Presence".

SINGH, DALJIT, "Pivoting Asia. Engaging China-American Strategy in East Asia Today", ISEAS perspective, 19 Oct 2012.

Submitted November 29, 2013

Accepted February 24, 2014

\begin{abstract}
This article is divided in three sections. The first one explores the so-called "strategic partnership" between Brazil and China. In the second section we shall examine how US-China relations in the global system could affect both Brazil-US, and Brazil-China bilateral relations. A final section presents some recommendations for Brazil strategic orientations regarding the current systemic transition in the allotment of global power.
\end{abstract}

Keywords: Brazilian Foreign Policy; global power transition; strategic partnership.

\title{
Resumo
}

Este artigo é dividido em três seções. A primeira explora a chamada "parceria estratégia" entre China e Brasil. Na segunda seção examina-se como as relações EUA-China no sistema global podem afetar as relações bilaterais entre Brasil-EUA e Brasil-China. A última seção apresenta recomendações acerca das orientações estratégicas do Brasil com relação ao atual sistema de transição de distribuição de poder global.

Palavras-chave: Política Externa Brasileira; transição de poder global; parceria estratégica. 